\title{
Nasal Cavity and Paranasal Sinuses Cancer Clinical TNM Finding v8
}

National Cancer Institute

\section{Source}

National Cancer Institute. Nasal Cavity and Paranasal Sinuses Cancer Clinical TNM

Finding v8. NCI Thesaurus. Code C133025.

A clinical finding about one or more characteristics of nasal cavity and paranasal sinuses cancer, following the rules of the TNM AJCC v8 classification system. 